\title{
NEW YEAR, NEW CENTURY, NEW MILLENIAL
}

\author{
On New Year's morning, I make coffee, turn on my computer, \\ and take a hot shower.
}

\section{Everything I need is here.}

This New Year, New Centennial, New Millennial will be my only one.

\section{Carpe diem!}

I will stay home and be grateful for the people and places in my life.

Tempus Fugit!

How delicious it is to not make a list of resolutions.

How great that my printer works!

The Day after Yesterday is the only day there is

for us still in bodies.

The Day before tomorrow

is the only day there is.

I am here. 